\title{
Electromagnetic Shielding Performance of Different Metallic Coatings Deposited by Arc Thermal Spray Process
}

\author{
Jong-Min Jang ${ }^{1}$, Han-Seung Lee ${ }^{2, *(\mathbb{D})}$ and Jitendra Kumar Singh ${ }^{1, *(\mathbb{D})}$ \\ 1 Innovative Durable Building and Infrastructure Research Center, Department of Architectural Engineering, \\ Hanyang University, 1271 Sa3-dong, Sangrok-gu, Ansan 15588, Korea; jangjm@hanyang.ac.kr \\ 2 Department of Architectural Engineering, Hanyang University, 1271 Sa 3-dong, Sangrok-gu, Ansan 15588, Korea \\ * Correspondence: ercleehs@hanyang.ac.kr (H.-S.L.); jk200386@hanyang.ac.kr (J.K.S.); Tel.: +82-31-436-8159 (J.K.S.)
}

Received: 9 November 2020; Accepted: 15 December 2020; Published: 17 December 2020

\begin{abstract}
Advancement in electronic and communication technologies bring us up to date, but it causes electromagnetic interference (EMI) resulting in failure of building and infrastructure, hospital, military base, nuclear plant, and sensitive electronics. Therefore, it is of the utmost importance to prevent the failure of structures and electronic components from EMI using conducting coating. In the present study, $\mathrm{Cu}, \mathrm{Cu}-\mathrm{Zn}$, and $\mathrm{Cu}-\mathrm{Ni}$ coating was deposited in different thicknesses and their morphology, composition, conductivity, and EMI shielding effectiveness are assessed. The scanning electron microscopy (SEM) results show that $100 \mu \mathrm{m}$ coating possesses severe defects and porosity but once the thickness is increased to $500 \mu \mathrm{m}$, the porosity and electrical conductivity is gradually decreased and increased, respectively. $\mathrm{Cu}-\mathrm{Zn}$ coating exhibited lowest in porosity, dense, and compact morphology. As the thickness of coating is increased, the EMI shielding effectiveness is increased. Moreover, $100 \mu \mathrm{m} \mathrm{Cu}-\mathrm{Zn}$ coating shows $80 \mathrm{~dB}$ EMI shielding effectiveness at $1 \mathrm{GHz}$ but $\mathrm{Cu}$ and $\mathrm{Cu}-\mathrm{Ni}$ are found to be 68 and $12 \mathrm{~dB}$, respectively. EMI shielding effectiveness results reveal that $100 \mu \mathrm{m}$ $\mathrm{Cu}-\mathrm{Zn}$ coating satisfy the minimum requirement for EMI shielding while $\mathrm{Cu}$ and $\mathrm{Cu}-\mathrm{Ni}$ required higher thickness.
\end{abstract}

Keywords: metallic coatings; arc thermal spray; scanning electron microscope; X-ray diffraction; conductivity; EMI shielding

\section{Introduction}

The development of electronics and communication technologies cause us to advance but they adversely affect the building and infrastructure, hospital, military base, nuclear plant, and sensitive electronics owing to the augmentation in electromagnetic interference (EMI). The electronic science and technology cause electromagnetic radiation, which is the fifth most prevalent pollution after air, water, noise, and solid waste of the world [1]. It not only affects the aforementioned structures but also human health [2-4]. Therefore, it is of the utmost importance to prevent the damages of structures caused by electronic devices from the EMI. It can be achieved by shielding the surrounding structure using mechanically and electrically conducting materials. The electrical conductivity of the shielding materials can be obtained by mixing with carbon or highly conductive metals [5-9] or materials [10]. The conductivity of the materials can be increased by incorporating graphene, carbon foam, multi-walled carbon nano tubes, 2D metal carbide, etc., but these are complex and energy-intensive, which caused difficulties in scaling them for high-volume manufacturing [11].

There is a typical process to assemble/fabricate the shielding structure by bolting or welding of metal sheets and panels. However, they show a lower degree of shielding effectiveness attributed 
to the formation of oxides as well as imperfection of shape and surface [12,13]. The EMI shielding effectiveness depends on electrical conductivity, permeability, and thickness of the materials. There are different technologies developed by the researchers worldwide to reduce the effect of EMI using metallic materials, thin films, conductive polymers, and composites as electromagnetic shielding materials [14-18]. One of the best methods is to use conductive metal plates, alloying, or conventional process i.e., coatings to reduce EMI effect. The lightweight metals and alloys i.e., $\mathrm{Mg}$, are widely used in EMI shielding owing to their relatively good conductivity and basal texture intensity [19]. The alloying of $\mathrm{Al}, \mathrm{Sn}, \mathrm{Y}$, and $\mathrm{Gd}$ in $\mathrm{Mg}$ decreases the EMI shielding effectiveness, which could be attributed to the decrease in conductivity of the binary alloy [20]. The addition of different amounts of Ti in Mg decreases the conductivity but the EMI shielding effectiveness at ranges of 8.2-12.4 GHz increased compared to pure $\mathrm{Mg}$ attributed to the decrease in reflection loss and simultaneous absorption coefficient [21]. Ce could improve the EMI shielding effectiveness of the $\mathrm{Mg}$ matrix owing to the increased reflection and multiple reflection loss [22].

The stacking of the different layers to make composites improve the EMI shielding effectiveness compared to bulk thickness of $\mathrm{K}_{2} \mathrm{CrO}_{4}$-polymethyl methacrylate (PMMA) composites owing to the absorption loss [23]. The staked layer of multiwall carbon nano tube/PMMA exhibited higher shielding effectiveness than a single layer [24]. There are different constraints to use the metal plate, polymer, and composites such as high weight/density and cost. Thus, coating is the best option to reduce the effect of EMI as shielding materials. However, EMI of deposited coating can be affected by bulkiness and susceptibility to the corrosion or lack of structural flexibility [25-31]. The conducting metal can be used as foil, laminates, lacquer, sputter coating, vacuum deposition, flame and arc spraying, and electroless plating [32-38]. Among these processes, the arc thermal spray process is most widely used to deposit the conducting metals, alloys, and plastics, which impart the good shielding properties [39]. The arc thermal spray process is carried out by melting the oppositely charged consumable twin wires electrode to form an arc and then propelling the molten metal particles by compressed air onto the substrate (to be deposited) [40].

The Al-Zn coating has been deposited by arc thermal spray process onto the steel plate as well as concrete substrate, which shows the significant improvement in EMI attributed to the reflection loss [41,42]. Zn content increases the shielding value in the T6 states of Mg-4Zn alloys [43]. Cu is the metal being used as EMI shielding materials owing to its high absorption capacity of radio and magnetic waves as well as electrical conductivity, which is identical to silver and is economical [44]. However, platinum, gold, and silver are highly conductive but extremely expensive, thus, these metals cannot be used as EMI shielding materials [45]. Although, $\mathrm{Cu}$ is susceptible to corrosion and oxidation, which can be improved by the addition of $\mathrm{Ni}$ that is corrosion resistant with lower conductivity [46]. $\mathrm{Ni}$ is also expensive; thus, it can be used in fiber form rather than plate or panel. Ni fiber significantly improved the shielding effectiveness of cement-based materials [47]. Moreover, the electroplated $\mathrm{Ni}-\mathrm{P} / \mathrm{Cu}-\mathrm{Ni}$ polyester fabric exhibited higher EMI shielding compared to Ni-P owing to the increase in electrical conductivity of $\mathrm{Cu}$ and crystallinity of $\mathrm{Cu}-\mathrm{Ni}$ film [48].

The present study is emphasized to protect the national security building, military base camp, hospital, etc., from EMI at $1.0 \mathrm{GHz}$, which required minimum $80 \mathrm{~dB}$ shielding value [12] to attenuate the shielding materials and is recommended by national defense and military facilities as well as MIL-STD-188-125-1 (a common specification of the US Ministry of Defense; and DMFC 4-70-30) [13]. Thus, we have used $\mathrm{Cu}$ as a parent metal along with $\mathrm{Zn}$ and Ni for deposition of 100, 200, and $500 \mu \mathrm{m}$ coating using arc thermal spray process, which can achieve the minimum required EMI shielding. The variables are coatings $(\mathrm{Cu}, \mathrm{Cu}-\mathrm{Zn}$, and $\mathrm{Cu}-\mathrm{Ni})$ and thicknesses $(100,200$ and $500 \mu \mathrm{m})$ of each coating chosen for evaluation of EMI shielding effectiveness. The EMI shielding performance was evaluated at 0.1-1.0 GHz. The correlation of the surface morphology and texture have been established with the EMI shielding value. 


\section{Materials and Methods}

\subsection{Materials and Process of Coatings}

The $\mathrm{Cu}, \mathrm{Cu}-\mathrm{Zn}$, and $\mathrm{Cu}-\mathrm{Ni}$ coating was deposited onto the smooth steel substrate by the arc thermal spray process. In the arc thermal spray process, twin wires were melted at $30 \mathrm{~V}$ and $200 \mathrm{~mA}$ on arcing point and with the help of compressed air on 7.5 bars, the molten metal particles are propelled, resulting in deposition of coating by keeping the substrate away from the spray gun on $15-20 \mathrm{~cm}$ as described in our earlier publications [49-56]. The deposition of $\mathrm{Cu}$ coating was carried out by twin wires of $\mathrm{Cu}$ while for $\mathrm{Cu}-\mathrm{Zn}$ and $\mathrm{Cu}-\mathrm{Ni}$, one wire (wire-1) was $\mathrm{Cu}$ and another (wire-2) was $\mathrm{Zn}$ (Cu-Zn coating) and $\mathrm{Ni}(\mathrm{Cu}-\mathrm{Ni}$ coating) as described in Table 1. The wire diameter for all metals was $1.6 \mathrm{~mm}$ and the metal purity was $99.95 \mathrm{wt} . \%$ each. The digital images of $\mathrm{Cu}, \mathrm{Zn}$, and Ni wires are shown in Figure S1 (Supplementary Figure S1). Different coatings $(\mathrm{Cu}, \mathrm{Cu}-\mathrm{Zn}$, and $\mathrm{Cu}-\mathrm{Ni})$ and thicknesses $(100,200$, and $500 \mu \mathrm{m})$ were chosen for the evaluation of EMI shielding value. The coating $(100,200$, and $500 \mu \mathrm{m})$ was detached from the steel substrate by sharp knife for characterization i.e., scanning electron microscopy (SEM), X-ray diffraction (XRD), electrical conductivity, and EMI shielding effectiveness measurements.

Table 1. Experimental variables (coating and thickness).

\begin{tabular}{|c|c|c|c|}
\hline \multirow{2}{*}{ Coating } & \multicolumn{2}{|c|}{ For Deposition of Coating } & \multirow{2}{*}{ Thickness $(\mu \mathrm{m})$ of Coating } \\
\hline & Wire-1 & Wire-2 & \\
\hline \multirow{3}{*}{$\mathrm{Cu}$} & \multirow{3}{*}{$\mathrm{Cu}$} & \multirow{3}{*}{$\mathrm{Cu}$} & 100 \\
\hline & & & 200 \\
\hline & & & 500 \\
\hline \multirow{3}{*}{$\mathrm{Cu}-\mathrm{Zn}$} & \multirow{3}{*}{$\mathrm{Cu}$} & \multirow{3}{*}{$\mathrm{Zn}$} & 100 \\
\hline & & & 200 \\
\hline & & & 500 \\
\hline \multirow{3}{*}{$\mathrm{Cu}-\mathrm{Ni}$} & \multirow{3}{*}{$\mathrm{Cu}$} & \multirow{3}{*}{$\mathrm{Ni}$} & 100 \\
\hline & & & 200 \\
\hline & & & 500 \\
\hline
\end{tabular}

\subsection{Characterization of Coatings}

The top/outer surface and cross section morphology of different coatings $(\mathrm{Cu}, \mathrm{Cu}-\mathrm{Zn}$, and $\mathrm{Cu}-\mathrm{Ni})$ and thicknesses $(100,200$, and $500 \mu \mathrm{m})$ detached from the steel substrate was performed by scanning electron microscopy (SEM, HITACHI-S5000, Chiyoda City, Tokyo, Japan) operated at $15 \mathrm{kV}$ and elemental analysis by energy-dispersive $\mathrm{X}$-ray spectroscopy (EDS). The porosity of coatings after deposition was determined by ImageJ software (version 1.52n).

The nature of $\mathrm{Cu}, \mathrm{Cu}-\mathrm{Zn}$, and $\mathrm{Cu}-\mathrm{Ni}$ coatings was evaluated by $\mathrm{X}$-ray diffraction (XRD, Rigaku, Tokyo, Japan) using $\mathrm{Cu} \mathrm{K} \mathrm{K}_{\alpha}$ radiation $(\lambda=1.54059 \AA)$ generated on $40 \mathrm{kV}$ and $100 \mathrm{~mA}$ from $2 \theta=10-90^{\circ}$ at $4^{\circ} / \mathrm{min}$ scan rate.

\subsection{Conductivity Measurement of Coatings}

The electrical conductivity of coatings was measured by Loresta-GX MCP-T700 (Nittoseiko Analytech Co. Ltd., Kanagawa, Yamato, Chuorinkan, Japan) at four different locations and the average was reported in the result. Four-point probes were used, where two points are inside the electrode for voltage while the other two points are outside for current. 


\subsection{EMI Shielding Evaluation of Coatings}

The electromagnetic shielding performance of coatings was measured according to ASTM D4935 [57]. In this method, each material was to be tested with a reference specimen where the reference specimen was composed of a donut-shape with $133.1 \mathrm{~mm}$ outer and $76.2 \mathrm{~mm}$ inner diameter while the test and load specimen diameter was 33 and $133.1 \mathrm{~mm}$, respectively as shown in Figure 1 and described by Munalli et al. [58]. The measurement was performed by E5071C network analyzer (Keysight Technologies, Yeouido-dong, Yeongdeungpo-gu, Seoul, Korea) and a PNR2205-10 coaxial fixed attenuator (L3Harris Narda-ATM, Dongbaekjungang-Ro, Beon-Gil Gilheung-Gu, Yongin-Si, Gyeonggi-Do, Korea). The electromagnetic waves were provided through port 1 from 0.1 to $1 \mathrm{GHz}$ at different frequency variables while the results were collected at port 2 and analyzed by a network analyzer (Figure 1). The coatings specimens were kept in the middle as shown in Figure 1.

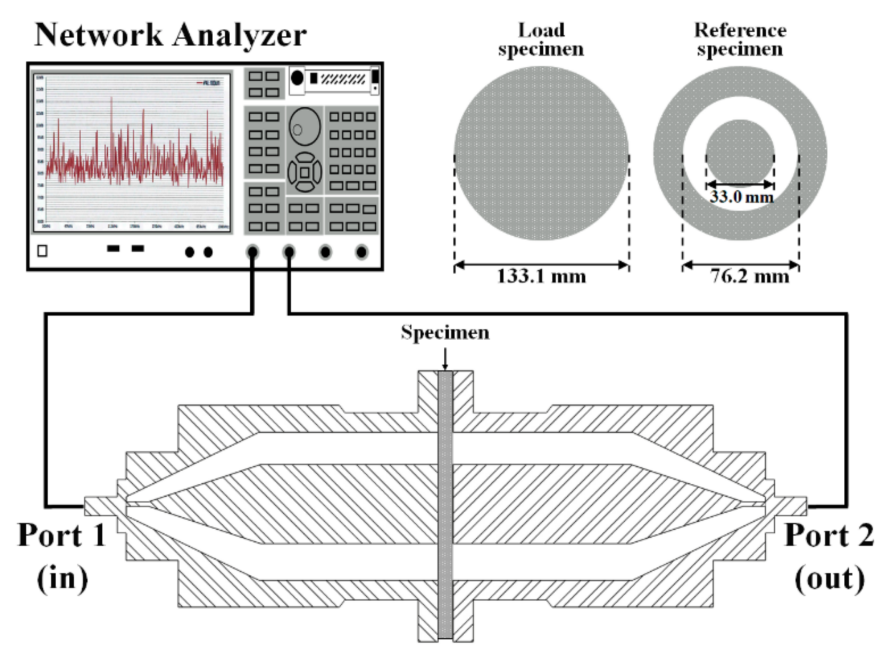

Figure 1. Schematic of E5071C network analyzer for electromagnetic interference (EMI) shielding effectiveness measurement.

The EMI shielding effectiveness was measured through the intensity of the received electromagnetic wave after passing through the reference specimen and the test specimen by irradiating electromagnetic waves of arbitrary frequency along the coaxial cable. The EMI shielding effectiveness can be measured by

$$
S E(d B)=20 \log \left|1+\frac{Z_{0}}{2\left(Z_{L}+Z_{C}\right)}\right|
$$

where $Z_{0}$ is the characteristic value $(50 \Omega)$ of the coaxial cable, and $Z_{L}$ and $Z_{c}$ are the impedance of the material under test and contact impedance, respectively.

\section{Results and Discussion}

The thickness of the coating was measured with non-destructive Elcometer456 (Tokyo, Japan) by randomly selecting three different locations, and the average is reported in the manuscript. The coating thickness was also verified with the cross-section SEM images. The thickness of all coatings measured with Elcometer456 is found to be around $100( \pm 5), 200( \pm 10)$, and $500( \pm 20) \mu \mathrm{m}$.

\subsection{SEM of Coatings}

The cross-sectional SEM images of 100, 200, and $500 \mu \mathrm{m}$ coatings are shown in Figures S2-S4, respectively. The coating thickness of $\mathrm{Cu}, \mathrm{Cu}-\mathrm{Zn}$, and $\mathrm{Cu}-\mathrm{Ni}$ measured by cross sectional SEM images is found to be $100( \pm 3)$ (Figure S2), $200( \pm 7)$ (Figure S3), and $500( \pm 6) \mu \mathrm{m}$ (Figure S4). The coating thickness obtained by SEM images are in good agreement with the result measured by Elcometer456. The surface morphology of the $\mathrm{Cu}, \mathrm{Cu}-\mathrm{Zn}$, and $\mathrm{Cu}-\mathrm{Ni}$ coatings with different thicknesses are shown in 
Figures 2-4. The SEM images of $100 \mu \mathrm{m}$ thick $\mathrm{Cu}, \mathrm{Cu}-\mathrm{Zn}$, and $\mathrm{Cu}-\mathrm{Ni}$ coating at $1000 \times$ are shown in Figure 2. It can be seen from Figure 2a and Figure S2a that the 100- $\mu \mathrm{m} \mathrm{Cu}$ coating exhibited defects and cracking attributed to the presence of splats particles resulting in the formation of space between two molten $\mathrm{Cu}$ particles. The deposition efficiency and quality of coating are directly related to deposition speed. In the present study, the deposition speed was $25 \mu \mathrm{m} / \mathrm{spray}$ pass, which is higher than normal process [59]. The semi-disk-shaped splat particles become flattened, which is attributed to the kinetic energy of the molten droplets where the velocity of the spraying is determined the morphology [60]. Thus, the pores and cracking are observed after solidification of the molten metal particles. These defects/pores and splat particles may allow the electromagnetic waves to pass during the EMI shielding effectiveness measurement. However, once the $\mathrm{Zn}$ (wire 2) is used along with $\mathrm{Cu}$ (wire 1), the morphology of $\mathrm{Cu}-\mathrm{Zn}$ film is improved as observed in Figure $2 \mathrm{~b}$ and Figure S2b, attributed to the melting point and density difference of $\mathrm{Cu}$ and $\mathrm{Zn}$. $\mathrm{Cu}$ (density: $8.96 \mathrm{~g} / \mathrm{cm}^{3}$ ) melts at $1085{ }^{\circ} \mathrm{C}$ while $\mathrm{Zn}$ (density: $7.13 \mathrm{~g} / \mathrm{cm}^{3}$ ) at $420{ }^{\circ} \mathrm{C}$. There are huge differences in density and melting points of $\mathrm{Cu}$ and $\mathrm{Zn}$. Cu exhibited higher density and melting points compared to $\mathrm{Zn}$, which required higher temperature to melt the metal. However, at this temperature i.e., $1085{ }^{\circ} \mathrm{C}$, there is a possibility that $\mathrm{Zn}$ can melt homogeneously, and the molten metal droplets become smaller compared to $\mathrm{Cu}$, which subsequently fill out the defects and pores of $\mathrm{Cu}$; thus, dense, compact, and regular morphology is observed in Cu-Zn coating (Figure $2 b$ and Figure S2b). Conversely, there are severe defects and pores observed by $100 \mu \mathrm{m} \mathrm{Cu}-\mathrm{Ni}$ film as shown in Figure 2c and Figure S2c. Cu and Ni both have almost identical densities, but the melting point is different. Ni melts at $1455^{\circ} \mathrm{C}$ while $\mathrm{Cu}$ at $1085{ }^{\circ} \mathrm{C}$. In this case, until the Ni melts, the $\mathrm{Cu}$ make the homogeneous solution of molten metal particles, but Ni does not melt completely; thus, some non-molten Ni droplets deposit onto the coating surface, resulting in the formation of heavy defects. $\mathrm{Cu}$ and $\mathrm{Ni}$ have identical density but different melting points, where $\mathrm{Cu}$ can melt and deposit early while Ni does so later, resulting in difference in coating composition owing to the unsaturated solution of $\mathrm{Cu}-\mathrm{Ni}$. The difference in melting point of identical density metal creates severe defects and pores owing to the deposition of different layer with different composition.

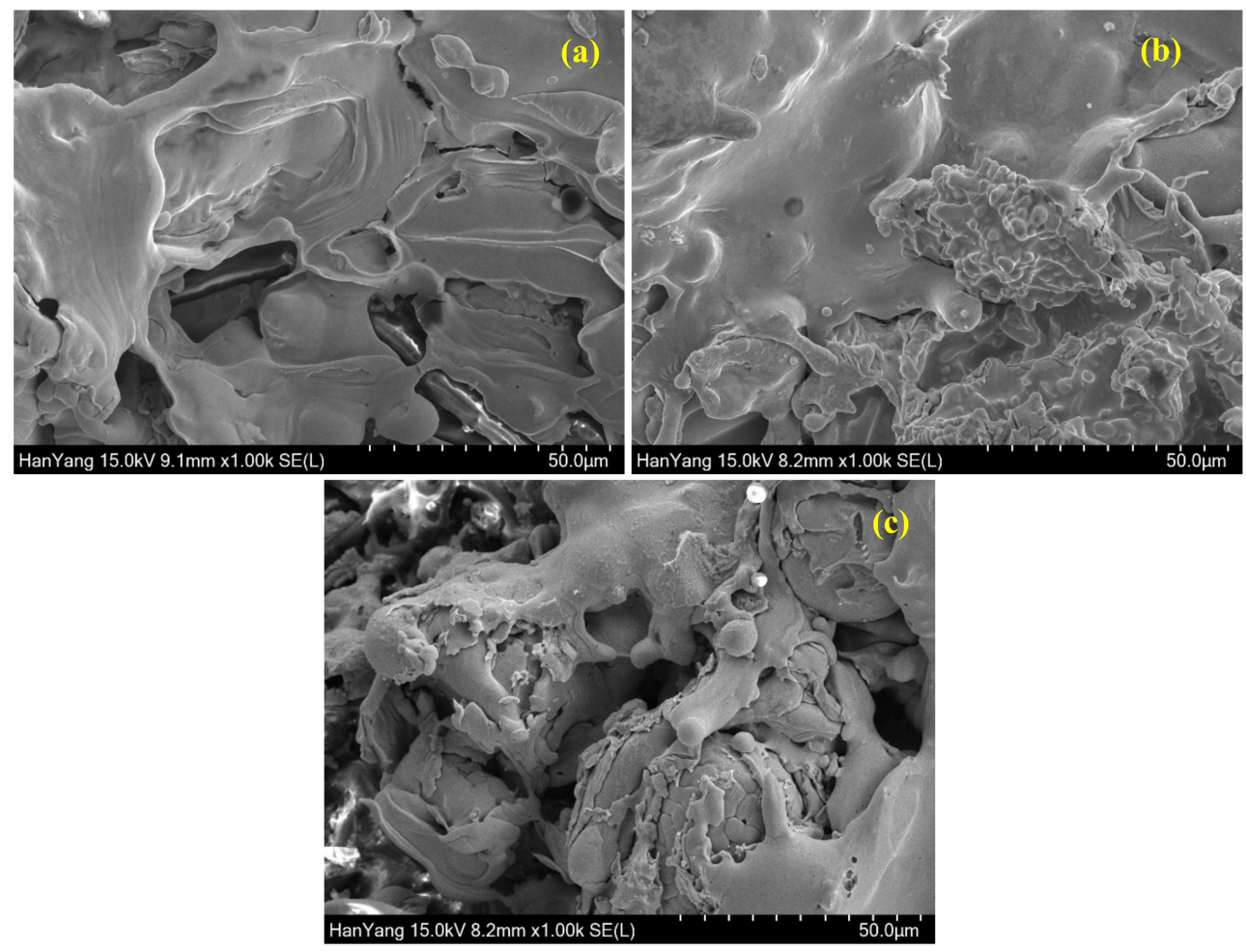

Figure 2. SEM images of $100 \mu \mathrm{m}$ (a) $\mathrm{Cu}$, (b) $\mathrm{Cu}-\mathrm{Zn}$, and (c) Cu-Ni coating. 
As the thickness of coatings is increased, the required time to deposit the coatings is higher than at a lower thickness. In this case, a greater number of passes of spraying is required to deposit a thick coating. Therefore, there is the possibility to melt the metal particles homogeneously, resulting in less defective coating. There were eight passes required to deposit $200 \mu \mathrm{m}$ thick coatings of $\mathrm{Cu}, \mathrm{Cu}-\mathrm{Zn}$, and $\mathrm{Cu}-\mathrm{Ni}$. The top surface SEM images of $200 \mu \mathrm{m}$ thick $\mathrm{Cu}, \mathrm{Cu}-\mathrm{Zn}$, and $\mathrm{Cu}-\mathrm{Ni}$ coatings are shown in Figure 3, whereas the cross-section morphology is shown in Figure S3a-c, respectively. It can be seen from these Figures that the morphology of $200 \mu \mathrm{m}$ thick film improved compared to $100 \mu \mathrm{m}$. The $\mathrm{Cu}$ coating shows splat particles with reduced volume of defects. There is plate morphology observed in the 200- $\mu \mathrm{m}$ Cu coating (Figure 3a) attributed to the homogeneous melting of metal particles during deposition of coating. The smaller molten metal particles uniformly deposited resulted in less defective coating (Figure 3a and Figure S3a) compared to $100 \mu \mathrm{m}$. The $\mathrm{Cu}-\mathrm{Zn}$ coating exhibited uniform and dense morphology (Figure $3 b$ and Figure S3b) but there are some inflight particles observed attributed to the vast difference in melting point and density of $\mathrm{Cu}$ and $\mathrm{Zn}$. These inflight particles come from the molten $\mathrm{Zn}$ metal droplets and are suspended in the atmosphere (due to the vast difference in melting point of $\mathrm{Cu}$ and $\mathrm{Zn}$ ) during deposition of coating; but, once the coating process was stopped, they immediately cooled down and deposited onto the surface as inflight particles, thus, some defects are observed in Figure 3b. However, the Cu-Ni coating shows defects (Figure 3c and Figure S3c) but lesser than $100 \mu \mathrm{m}$ and higher than $\mathrm{Cu}$ and $\mathrm{Cu}-\mathrm{Zn}$ coating. The $\mathrm{Cu}$ forms dense and compact morphology but some non-molten Ni deposit onto the coating, which causes defects even after eight spray passes. This result suggests that $\mathrm{Cu}-\mathrm{Ni}$ coating required higher thickness to get a good-quality film while $\mathrm{Cu}$ and $\mathrm{Cu}-\mathrm{Zn}$ can get by with $200 \mu \mathrm{m}$ coating. The defects/pores of Cu-Ni coating are open face (vertical) where electromagnetic waves can easily pass through it.


Figure 3. SEM images of $200 \mu \mathrm{m}$ (a) Cu, (b) Cu-Zn, and (c) Cu-Ni coating. 
As the coating thickness is increased, the morphology is improved significantly as shown in Figure 4 attributed to homogenous melting of metal particles. The deposition of thick coating requires a higher number of spray passes and time where the possibility to melt the high melting point metal such as $\mathrm{Cu}$ and $\mathrm{Ni}$ is higher resulting in homogenous melting. In the case of pure $\mathrm{Cu}$ coating to deposit $500 \mu \mathrm{m}$, both metal wires are melted in a significant amount of time where the particle size of molten metal droplets are very small, which subsequently cooled and uniformly deposited, resulting in dense, compact, and uniform morphology as shown in Figure $4 \mathrm{a}$ and Figure S4a. Alternatively, the Cu-Zn coating forms dense, regular, and smooth morphology (Figure $4 \mathrm{~b}$ and Figure $\mathrm{S} 4 \mathrm{~b}$ ) but there are some splat particles observed owing to the difference in melting point and density of $\mathrm{Cu}$ and $\mathrm{Zn}$. Moreover, even at $500 \mu \mathrm{m}$ thick $\mathrm{Cu}-\mathrm{Ni}$ coating, there are some defects, cracks (Figure S4c), as well as splat particles observed (Figure 4c), which refer to poor quality of the coating. The splat particles are probably Ni, which exhibit higher melting points. In all coatings, the defects are significantly reduced, attributed to the higher coating thickness.

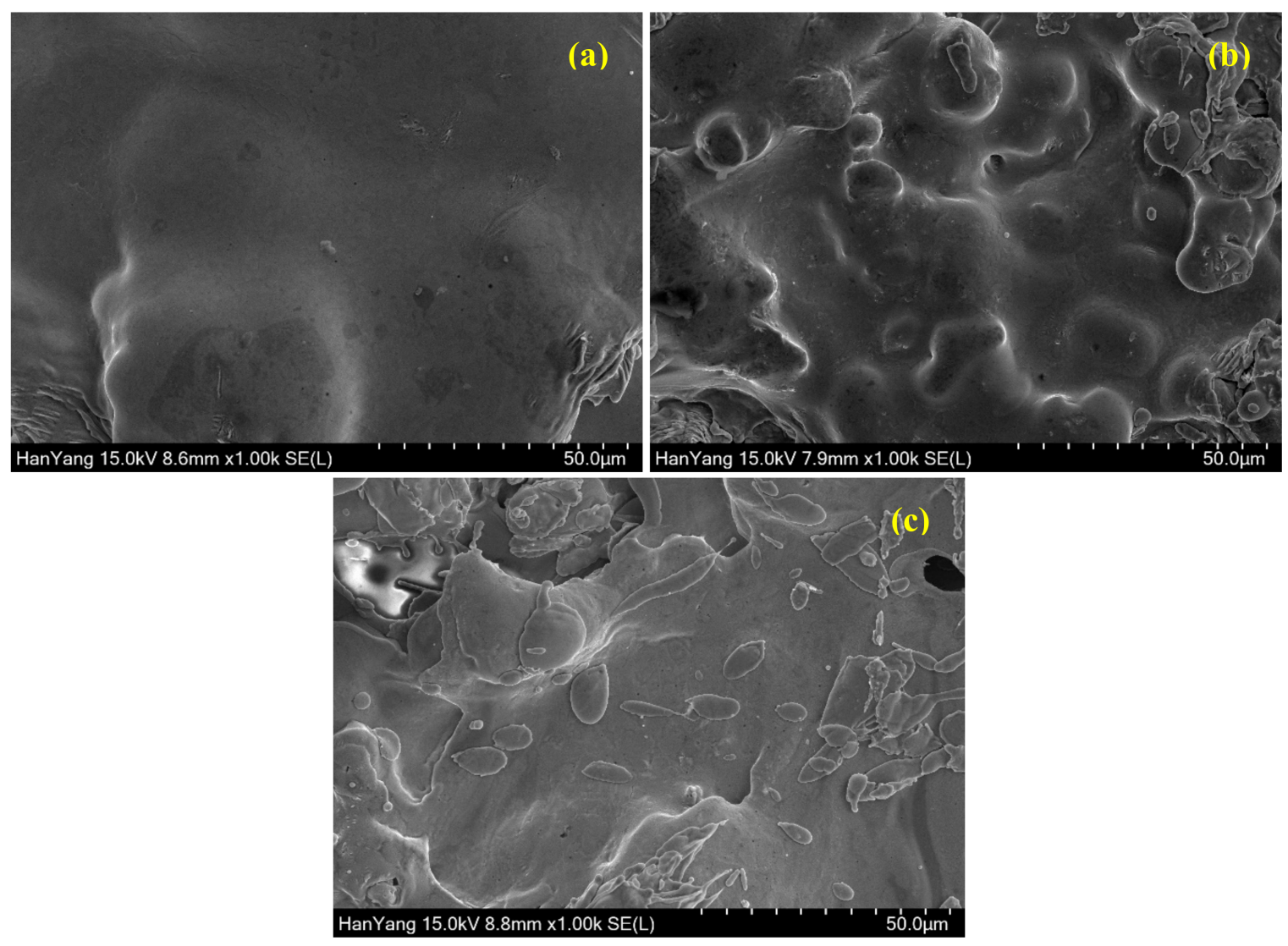

Figure 4. SEM images of $500 \mu \mathrm{m}(\mathbf{a}) \mathrm{Cu},(\mathbf{b}) \mathrm{Cu}-\mathrm{Zn}$, and (c) $\mathrm{Cu}-\mathrm{Ni}$ coating.

The porosity of the coatings on the outer surface as well as cross-section SEM images was measured by ImageJ software and the results are shown in Table 2. It can be seen from this table that lower coating thickness exhibited higher porosity but once the thickness increased, the porosity decreased gradually. The porosity measured on the outer surface as well as the cross section are in good agreement with each other. The $100 \mu \mathrm{m} \mathrm{Cu}-\mathrm{Ni}$ coating exhibited around 48-49\% porosity while $\mathrm{Cu}$ and $\mathrm{Cu}-\mathrm{Zn}$ show around $34-38 \%$ and $21 \%$, respectively. The $\mathrm{Cu}-\mathrm{Zn}$ coating exhibits the lowest value in porosity attributed to the deposition of the dense coating where smaller melted $\mathrm{Zn}$ particles sediment into the defects of the coating resulted in lower porosity. The $200 \mu \mathrm{m}$ thick $\mathrm{Cu}$ and $\mathrm{Cu}-\mathrm{Zn}$ film exhibited almost identical porosity (Table 2) and less than $100 \mu \mathrm{m}$ attributed to the deposition of dense and compact coating. As the coating thickness is increased up to $500 \mu \mathrm{m}$, the porosity of $\mathrm{Cu}$ and $\mathrm{Cu}-\mathrm{Zn}$ is found to be around $7-8 \%$, which is reduced by around $80-81 \%$ and $62 \%$ compared to $100 \mu \mathrm{m}$, respectively. However, 
Cu-Ni exhibits $23 \%$ porosity, which is reduced by around $52-53 \%$ compared to $100 \mu \mathrm{m}$. This result suggests that once the coating thickness is increased from 100 to $500 \mu \mathrm{m}$, all of the coatings porosities are reduced by more than $50 \%$.

Table 2. Porosity measurement (\%) and EDS analysis of coatings.

\begin{tabular}{cccccccc}
\hline \multirow{2}{*}{ Coatings } & \multirow{2}{*}{ Thickness $(\mu \mathrm{m})$} & \multicolumn{3}{c}{ Porosity (\%) } & \multicolumn{3}{c}{ Elements (wt.\%) } \\
\cline { 2 - 8 } & & Outer/Top Surface & Cross Section & Cu & Zn & Ni & O \\
\hline \multirow{3}{*}{ Cu } & 100 & 38 & 34 & 99.78 & - & - & 0.22 \\
\cline { 2 - 8 } & 200 & 12 & 12 & 99.57 & - & - & 0.43 \\
\cline { 2 - 8 } & 500 & 7 & 7 & 99.60 & - & - & 0.40 \\
\hline \multirow{3}{*}{ Cu-Zn } & 100 & 21 & 21 & 32.52 & 66.34 & - & 1.14 \\
\cline { 2 - 8 } & 200 & 13 & 14 & 30.43 & 68.59 & - & 0.98 \\
\hline \multirow{3}{*}{ Cu-Ni } & 500 & 48 & 8 & 31.23 & 67.93 & - & 0.85 \\
\cline { 2 - 8 } & 100 & 27 & 49 & 49.62 & - & 47.40 & 2.98 \\
\cline { 2 - 8 } & 200 & 23 & 23 & 18.91 & - & 80.54 & 0.55 \\
\hline
\end{tabular}

The EDS analysis of $\mathrm{Cu}, \mathrm{Cu}-\mathrm{Zn}$, and $\mathrm{Cu}-\mathrm{Ni}$ coatings at different thickness is shown in Table 2. It can be seen from this table that the $\mathrm{Cu}$ coating in all thicknesses exhibited only $\mathrm{Cu}$ with nominal amount of $\mathrm{O}$ i.e., $0.22-0.43 \mathrm{wt}$.\% attributed to the atmospheric oxygen or inflight particles. The $\mathrm{O}$ in all coatings is very low, and the maximum amount was found to be in the $100 \mu \mathrm{m} \mathrm{Cu}-\mathrm{Ni}$ coating i.e., $2.98 \mathrm{wt} . \%$. The EDS analysis confirms that there is no oxidation of coating during deposition by arc thermal spray process attributed to the fast spraying i.e., $25 \mu \mathrm{m} / \mathrm{spray}$ where chances for oxidation of coating is minimum. The $\mathrm{O}$ in the coating might be coming from the atmosphere or inflight particles. There is an interesting observation can be found in EDS analysis of $\mathrm{Cu}-\mathrm{Zn}$ and $\mathrm{Cu}-\mathrm{Ni}$ coatings that they have formed pseudo alloy instead of pure. In $\mathrm{Cu}-\mathrm{Zn}$, the maximum amount is 66.34-68.59 wt.\% $\mathrm{Zn}$ while in the case of $\mathrm{Cu}-\mathrm{Ni}, \mathrm{Ni}$ is the maximum. It is attributed to the difference in density and melting point of the metals. In the $\mathrm{Cu}-\mathrm{Zn}$ coating, $\mathrm{Zn}$ exhibits a lower melting point as well as density compared to $\mathrm{Cu}$, which deposits onto the coating later. Zn melts early, and owing to the lower density, is suspended into the atmosphere during the spraying process, which later cools and deposits onto the surface, while due to the high density of $\mathrm{Cu}$, it preferably deposits. Thus, on the top surface, a lower density and melting point metal is observed i.e., $\mathrm{Zn}$ in a higher amount. Alternatively, for the $\mathrm{Cu}-\mathrm{Ni}$ coating, both metals have identical densities but the melting points are different. Ni has a higher melting point than $\mathrm{Cu}$, which requires more time to completely melt while $\mathrm{Cu}$ melts early and preferably deposits [61]; thus, the later one i.e., $\mathrm{Ni}$ is found to be in a higher amount are a higher thickness of coating, resulting in pseudo alloy formation. In the lower thickness of coating, $\mathrm{Cu}-\mathrm{Ni}$ deposits identical amounts and forms a Cu-Ni alloy, but as the thickness is increased, Ni content is found to be increased while $\mathrm{Cu}$ is decreased.

\subsection{XRD of Coating}

The XRD of $\mathrm{Cu}, \mathrm{Cu}-\mathrm{Zn}$, and $\mathrm{Cu}-\mathrm{Ni}$ coatings having different thicknesses, as shown in Figure 5. The XRD result of $100 \mu \mathrm{m}$ thick $\mathrm{Cu}, \mathrm{Cu}-\mathrm{Zn}$, and $\mathrm{Cu}-\mathrm{Ni}$ coating is shown in Figure 5a. It can be seen that $\mathrm{Cu}$ coating exhibited $\mathrm{Cu}$ (JCPD: 03-065-9026) having three lattice planes at (111), (200), and (220) while the $\mathrm{Cu}-\mathrm{Zn}$ coating exhibited identical Cu along with Zn (JCPDF: 03-065-5973) at (002), (100), (102), (103), (004), (112), and (201) plane. Alternatively, in the Cu-Ni coating, it shows $\mathrm{Cu}$ along with $\mathrm{Ni}$ (JCPDF: 03-065-0380). The lattice plane of $\mathrm{Ni}$ and $\mathrm{Cu}$ are identical, which can be attributed to the FCC structure of $\mathrm{Cu}$ and Ni. Thus, both phases show identical orientation in the lattice plane. The phases formed in the 200 (Figure 5b) and $500 \mu \mathrm{m}$ (Figure 5c) coatings are identical as observed in $100 \mu \mathrm{m}$. 
This result suggests that there is no alloying of $\mathrm{Zn}$ and $\mathrm{Ni}$ with $\mathrm{Cu}$ and oxidation is attributed to the coating process where it forms a mechanical bond rather than an intermetallic one [62] and fast deposition of coating by the arc thermal spraying process, respectively. There is no difference in peak intensity of $\mathrm{Cu}$ and $\mathrm{Zn}$ in $\mathrm{Cu}$ and the $\mathrm{Cu}-\mathrm{Zn}$ coating at different thicknesses. On the contrary, the Cu-Ni coating exhibited different peak intensity ratios of $\mathrm{Cu}$ and $\mathrm{Ni}$ at different thicknesses. As the thickness increased, the peak intensity of $\mathrm{Ni}$ at (111), (200), and (220) gradually increased while Cu is decreased, which is attributed to the higher participation of $\mathrm{Ni}$ in coating composition as observed in the EDS analysis (Table 2). Thus, it can be said that XRD and EDS results are in good correlation.
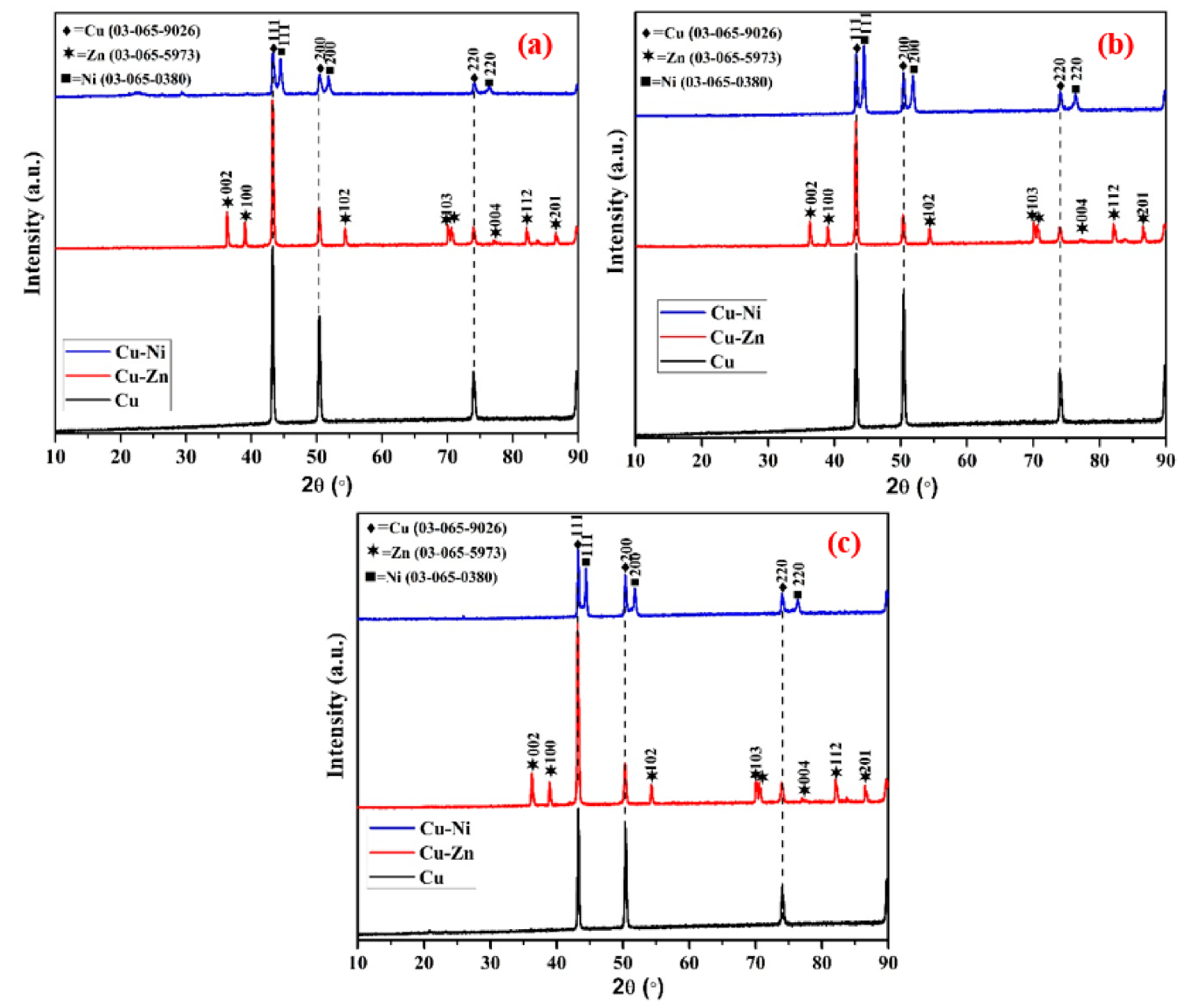

Figure 5. XRD of (a) 100, (b) 200, and (c) $500 \mu \mathrm{m} \mathrm{Cu}, \mathrm{Cu}-\mathrm{Zn}$, and Cu-Ni coatings.

\subsection{Electrical Conductivity of Coating}

The electrical conductivity of the coating is shown in Figure 6. The EMI shielding effectiveness depends on the electrical and physical properties of the deposited coatings as well as the interference between the coating and substrate. From Figure 6 it can be seen that as the thickness of the coating increased, the electrical conductivity gradually increased [63], which is attributed to the improved morphology where the metal particles are denser, compact, and regularly connected to each other as observed in Figure 4 and Figure S4. The electrical conductivity of the $100 \mu \mathrm{m} \mathrm{Cu}$-Zn coating is slightly higher compared to the $\mathrm{Cu}$, which is attributed to the lower porosity (Table 2). It is well known that higher porosity leads to lower conductivity. The $100 \mu \mathrm{m} \mathrm{Cu}-\mathrm{Ni}$ coating shows the lowest conductivity owing to the presence of heavy defects/pores in the film. From Figure 2c and Figure S2c, it can be seen that the $100 \mu \mathrm{m} \mathrm{Cu}-\mathrm{Ni}$ coating deposited by the arc thermal spray process possesses the highest porosity i.e., 48-49\% (Table 2), which decreases the conductivity as observed in Figure 6, which is 
attributed to the irregularity in deposition of the metal particles [64]. In the present study, there is no interference between the coating and substrate because the coating was detached from the smooth steel substrate by knife. On the other hand, as the coating thickness increased, the conductivity of each coating increased, which is attributed to the improved morphology. However, the $200 \mu \mathrm{m} \mathrm{Cu}$ coating shows higher conductivity compared to $\mathrm{Cu}-\mathrm{Zn}$ and $\mathrm{Cu}-\mathrm{Ni}$ while the porosity of $\mathrm{Cu}$ and $\mathrm{Cu}-\mathrm{Zn}$ films is almost identical. This result suggests that as the thickness is increased and the required time and spray passes to deposit the coating is increased, resulting in the molten metal particles become smaller than at lower thicknesses, which improved the conductivity because the metal with the lower melting point melts early and forms a dense structure and joins the molten metal droplets to each other. Moreover, the conductivity of $\mathrm{Cu}$ metal is higher compared to $\mathrm{Ni}$ and $\mathrm{Zn}$. In the case of the pure $\mathrm{Cu}$ coating, the porosity decreased as the thickness increased, which led to higher conductivity while in the case of $\mathrm{Cu}-\mathrm{Zn}$, the porosity decreased but owing to the low conductivity of $\mathrm{Zn}$, the conductivity of the coating is lower compared to $\mathrm{Cu}$. On the other hand, the $\mathrm{Cu}-\mathrm{Ni}$ coating possesses higher porosity even at $500 \mu \mathrm{m}$ thickness, which causes the discontinuity/irregularity in particles. Thus, the lowest conductivity is observed (Figure 6).



Figure 6. Electrical conductivity of coatings.

\subsection{Shielding Effectiveness Measurement}

The EMI shielding is considered by blocking the flow of an electromagnetic wave. Therefore, the shielding of electromagnetic waves can be represented by the sum of reflection $\left(S E_{R}\right)$, absorption $\left(S E_{A}\right)$, and multiple reflections $\left(S E_{M}\right)$ loss of materials i.e., $\mathrm{SE}=S E_{R}+S E_{A}+S E_{M}$ [65-67]. In this case, $S E_{M}$ can be ignored [7,68] if $S E_{R}$ is greater than $9 \mathrm{~dB}$. Therefore, $S E_{R}$ and $S E_{A}$ can be derived by Simon formalism $[69,70]$ :

$$
\mathrm{SE}=50+10 \log _{10}\left(\frac{1}{\rho \cdot f}\right)+1.7 t\left(\frac{f}{\rho}\right)^{\frac{1}{2}}
$$

where $\rho$ is the volume resistivity $(\Omega \cdot \mathrm{cm})$, which is the same as the reciprocal of the electrical conductivity $(\sigma), f$ is the frequency $(\mathrm{MHz})$, and $t$ is the thickness of the shielding material $(\mathrm{cm})$. Based on Equation $(2)$, it can be said that if the conductivity of the shielding material is high or thick, then the shielding effectiveness would be higher.

The EMI shielding effectivenss of different coating at various thicknesses are shown in Figure 7. The EMI shielding value is dependent on the frequency of electromagnetic waves. The minimum required shielding effectiveness for a national security building, military base camp, hospital, etc., from EMI is $80 \mathrm{~dB}$ at $1.0 \mathrm{GHz}$ [12]. Ninghi et al. have observed that at a high frequency, the EMI 
shielding effectiveness is decreased owing to the absorption loss and electrical/magnetic dipoles [71]. Thus, it is important to consider the EMI shielding effectiveness of coatings at $1.0 \mathrm{GHz}$. It can be seen from Figure $7 \mathrm{a}$ that the $100 \mu \mathrm{m} \mathrm{Cu}-\mathrm{Zn}$ coating exhibited around $80 \mathrm{~dB}$ at $1 \mathrm{GHz}$ while $\mathrm{Cu}$ is $68 \mathrm{~dB}$. This result suggests that the $\mathrm{Cu}-\mathrm{Zn}$ coating can only sustain and use the EMI shielding application if the coating thickness is considered $100 \mu \mathrm{m}$. The addition of $\mathrm{Zn}$ improved the EMI shielding effectiveness significantly [43]. Moreover, as the frequency increased from 0.1 to $1 \mathrm{GHz}$, the shielding effectiveness of $100 \mu \mathrm{m} \mathrm{Cu}$ and $\mathrm{Cu}-\mathrm{Ni}$ coatings decreased gradually, which is attributed to the decrease in reflection and increase in absorption loss of the electromagnetic waves. Due to the presence of heavy defects and pores, the electromagnetic waves are slightly leaked from the pores of the coatings and the fixture, which is inevitable where reflection loss is always dominant. Therefore, at high frequencies, the overall shielding efficiency of the coating is decreased. The presence of heavy defects in the $100 \mu \mathrm{m} \mathrm{Cu}-\mathrm{Ni}$ coating (Figure $2 \mathrm{c}$ and Figure S2c) leads to a lower electrical conductivity i.e., $23.8 \mathrm{~S} / \mathrm{cm}$ (Figure 6), which in turn reduces the reflection loss [22]; thus, the shielding value is found to be lowest (Figure 7a). As the thickness of coating is increased, the shielding effectiveness is increased as shown in Figure $7 \mathrm{~b}, \mathrm{c}$, which is attributed to the increase in electrical conductivity and absorption loss. It is observed in Figure 6 that as the thickness is increased, the conductiviy is increased. There is zig-zag in shielding effectiveness of high thickness coating attributed to the bumpy surface where electromagnetic waves can leak. It can be seen from Figure $7 \mathrm{~b}(200 \mu \mathrm{m})$ and Figure 7c $(500 \mu \mathrm{m})$ that $\mathrm{Cu}, \mathrm{Cu}-\mathrm{Zn}$, and $\mathrm{Cu}-\mathrm{Ni}$ achieved the required shielding value i.e., $80 \mathrm{~dB}$ at $1 \mathrm{GHz}$. This result suggests that these coatings with more than $100 \mu \mathrm{m}$ thick film is able to shield the EMI and can be used to protect the national security building, military base camp, hospital, etc. However, among all coatings, the $\mathrm{Cu}-\mathrm{Zn}$ coating exhibits greater performance in regards of EMI shielding value. The 200 and $500 \mu \mathrm{m} \mathrm{Cu}-\mathrm{Zn}$ coatings exhibited 89 and $95 \mathrm{~dB}$ EMI shielding effectiveness at $1 \mathrm{GHz}$, respectively. From this study, it can be concluded that surface morphology, porosity, thickness, composition, and electrical conductivity of the coatings are in good agreement with EMI shielding value. As the coating thickness is increased, the porosity is decreased (Table 2), and electrical conductivity (Figure 6) and shielding effectiveness is increased (Figure 7).
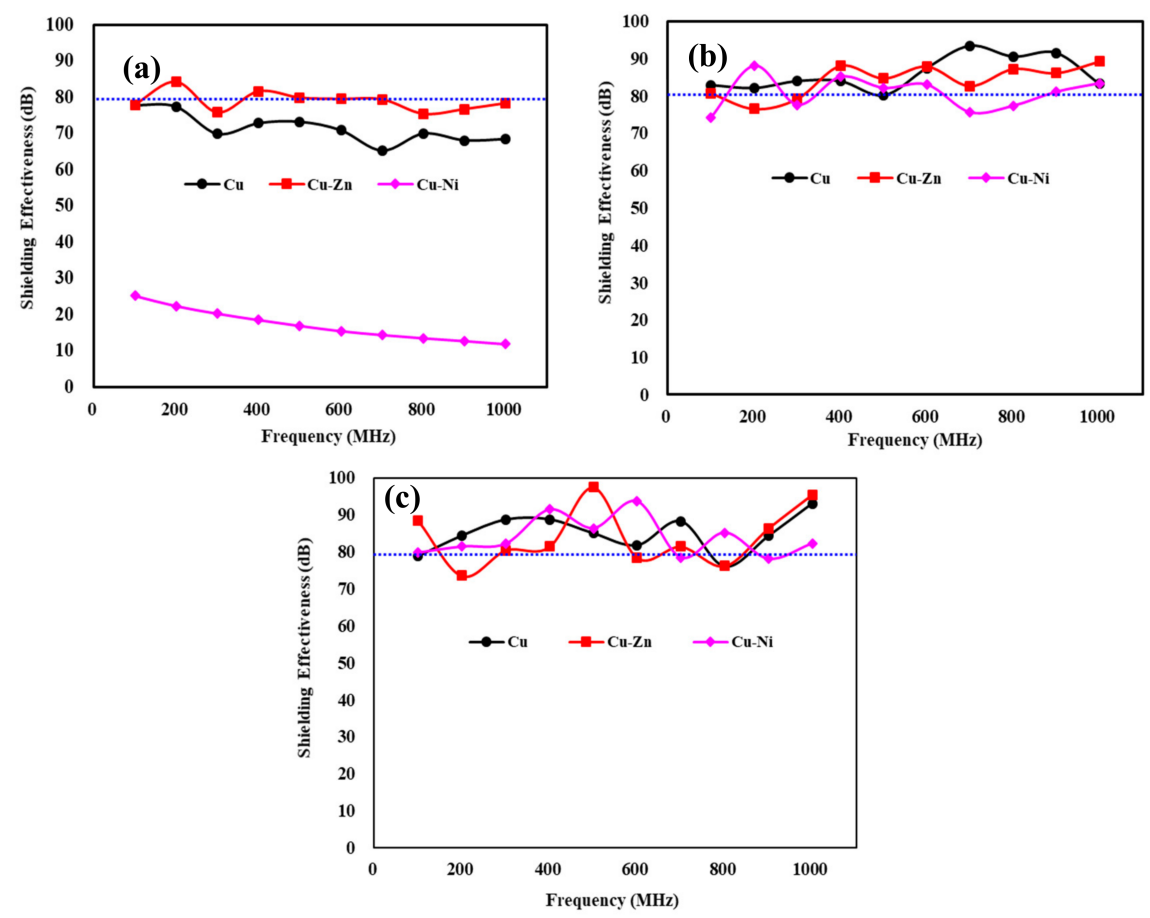

Figure 7. Shielding effectiveness value of (a) 100, (b) 200, and (c) $500 \mu \mathrm{m} \mathrm{Cu}, \mathrm{Cu}-\mathrm{Zn}$, and Cu-Ni coatings at different frequencies. 


\section{Conclusions}

In the present study, $\mathrm{Cu}, \mathrm{Cu}-\mathrm{Zn}$, and $\mathrm{Cu}-\mathrm{Ni}$ coatings were deposited by the arc thermal spray process in various thicknesses to shield the EMI, and their properties were assessed by SEM, XRD, electrical conductivity, and EMI shielding effectiveness. The $100 \mu \mathrm{m}$ coating exhibited greater defects and porosity attributed to the low spray pass and difference in melting points as well as the density of metals to be deposited. The $\mathrm{Cu}-\mathrm{Zn}$ coating showed improved surface morphology attributed to the lower melting point and density of $\mathrm{Zn}$ compared to the $\mathrm{Cu}$ and $\mathrm{Cu}-\mathrm{Ni}$ coatings. XRD results confirm that the $\mathrm{Cu}$ film exhibited only a $\mathrm{Cu}$ phase while the $\mathrm{Cu}-\mathrm{Zn}$ and $\mathrm{Cu}-\mathrm{Ni}$ coatings show $\mathrm{Zn}$ and $\mathrm{Ni}$ along with $\mathrm{Cu}$, which suggest that there is no formation of intermetallic layers or alloying during deposition by the arc thermal spray process. However, as the coating thickness of $\mathrm{Cu}-\mathrm{Ni}$ increased, the Ni content increased, as well as the intensity ratio of Ni peak. The $100 \mu \mathrm{m} \mathrm{Cu}$ coating exhibited lower conductivity, attributed to the higher porosity compared to $\mathrm{Cu}-\mathrm{Zn}$. As the coating thickness increased, the conductivity increased, which is attributed to the improved morphology and lower porosity. The $100 \mu \mathrm{m} \mathrm{Cu}-\mathrm{Zn}$ coating exhibited the minimum required EMI shielding value i.e., $80 \mathrm{~dB}$ at $1 \mathrm{GHz}$, which reveals that this coating can be used to impart the EMI shielding. However, the $100 \mu \mathrm{m} \mathrm{Cu}$ and $\mathrm{Cu}-\mathrm{Ni}$ coatings showed lower EMI shielding effectiveness compared to the minimum requirement, which is attributed to the presence of heavy defects and pores where the electromagnetic waves leaked slightly between the pores of coating and the fixture, which is inevitable. These coatings also showed the gradual decrement in EMI shielding effectiveness as the frequency increased, owing to the decrease in reflection loss and increase in absorption loss of the electromagnetic waves. Once the coating thickness increased greater than $100 \mu \mathrm{m}$, all coatings exhibited the minimum required EMI shielding value i.e., $80 \mathrm{~dB}$ at $1 \mathrm{GHz}$, attributed to the improvement in morphology, decrease in porosity, and increase in electrical conductivity where molten metal particles are well-connected to each other, resulting in the formation of a dense and compact coating, which leads to increased EMI shielding effectiveness. This study suggests that instead of using pure $\mathrm{Cu}$ metal plates or coatings for EMI shielding, a $100 \mu \mathrm{m} \mathrm{Cu}-\mathrm{Zn}$ coating could be used, which is cost effective and effective for EMI shielding.

Supplementary Materials: The following are available online at http://www.mdpi.com/1996-1944/13/24/5776/s1, Figure S1: $1.6 \mathrm{~mm}$ diameter wire of (a) Cu, (b) Zn and (c) Ni, Figure S2: Cross section SEM images of $100 \mu \mathrm{m}$ (a) Cu, (b) Cu-Zn and (c) Cu-Ni film at 200×, Figure S3: Cross section SEM images of $200 \mu \mathrm{m}$ (a) Cu, (b) Cu-Zn and (c) Cu-Ni film at 200×, Figure S4: Cross section SEM images of $500 \mu \mathrm{m}$ (a) Cu, (b) Cu-Zn and (c) Cu-Ni film at $100 \times$.

Author Contributions: Data curation, J.-M.J. and J.K.S.; formal analysis, J.-M.J. and J.K.S.; funding acquisition, H.-S.L.; investigation, J.-M.J.; methodology, J.-M.J.; project administration, H.-S.L.; resources, H.-S.L.; supervision, H.-S.L. and J.K.S.; writing-original draft, J.-M.J., J.K.S., and H.-S.L.; writing-review and editing, J.-M.J., J.K.S., and H.-S.L. All authors have read and agreed to the published version of the manuscript.

Funding: This research received no external funding.

Acknowledgments: This research was supported by a grant (18SCIP-B146646-01) from the Construction Technology Research Project funded by the Ministry of Land, Infrastructure and Transport of Korea government.

Conflicts of Interest: All authors declare that there is no known conflict of interest.

\section{References}

1. Wang, J.; Zhou, H.; Zhuang, J.; Liu, Q. Influence of spatial configurations on electromagnetic interference shielding of ordered mesoporous carbon/ordered mesoporous silica/silica composites. Sci. Rep. 2013, 3, 3252. [CrossRef] [PubMed]

2. Gut, J. The Swiss EMP concept of general defense. IEEE Antennas Propag. Soc. Newsl. 1987, $29,4-10$. [CrossRef]

3. Fugetsu, B.; Sano, E.; Sunada, M.; Sambongi, Y.; Shibuya, T.; Wang, X.; Hiraki, T. Electrical conductivity and electromagnetic interference shielding efficiency of carbon nanotube/cellulose composite paper. Carbon 2008, 46, 1256-1258. [CrossRef] 
4. Brillaud, E.; Piotrowski, A.; de Seze, R. Effect of an acute $900 \mathrm{MHz}$ GSM exposure on glia in the rat brain: A time-dependent study. Toxicology 2007, 238, 23-33. [CrossRef]

5. Xu, X.B.; Li, Z.-M.; Shi, L.; Bian, X.-C.; Xiang, Z.-D. Ultralight conductive carbon-nanotube-polymer composite. Small 2007, 3, 408-411. [CrossRef]

6. Nam, I.W.; Kim, H.K.; Lee, H.K. Influence of silica fume additions on electromagnetic interference shielding effectiveness of multi-walled carbon nanotube/cement composites. Constr. Build. Mater. 2012, 30, 480-487. [CrossRef]

7. Chung, D.-D.-L. Electromagnetic interference shielding effectiveness of carbon materials. Carbon 2001, 39, 279-285. [CrossRef]

8. Kim, H.-K.; Nam, I.-W.; Lee, H.-K. Enhanced effect of carbon nanotube on mechanical and electrical properties of cement composites by incorporation of silica fume. Compos. Struct. 2014, 107, 60-69. [CrossRef]

9. Khushnood, R.-A.; Ahmad, S.; Savi, P.; Tulliani, J.-M.; Giorcelli, M.; Ferro, G.-A. Improvement in electromagnetic interference shielding effectiveness of cement composites using carbonaceous nano/micro inerts. Constr. Build. Mater. 2015, 85, 208-216. [CrossRef]

10. Osawa, Z.; Kuwabara, S. Thermal stability of the shielding effectiveness of composites to electromagnetic interference. Effects of matrix polymers and surface treatment of fillers. Polym. Degrad. Stab. 1992, 35, $33-43$. [CrossRef]

11. Park, J.; Hu, X.; Torfeh, M.; Okoroanyanwu, U.; Arbabi, A.; Watkins, J.J. Exceptional electromagnetic shielding efficiency of silver coated carbon fiber fabrics via a roll-to-roll spray coating process. J. Mater. Chem. C 2020, 8, 11070-11078. [CrossRef]

12. MIL-STD-188-125-1, High-Altitude Electromagnetic Pulse(HEMP) Protection for Ground-Based C4I Facilities Performing Critical, Time-Urgent Missions Part 1 Fixed Facilities; Department of Defense Interface Standard, Department of Defense: Alexandria, VA, USA, 1998.

13. IEEE Std 299. IEEE Standard Method for Measuring the Shielding Effectiveness of ELECTROMAGNETIC Shielding Enclosures; IEEE: Piscataway, NJ, USA, 2006; p. 50.

14. Savage, E.; Gilbert, J.; Radasky, W. The Early-Time (E1) High-Altitude Electromagnetic Pulse (HEMP) and Its Impact on the US Power Grid. Report Meta-R-320 for Oak Ridge National Laboratory. 2010. Available online: https://www.eiscouncil.org/App_Data/Upload/9b03e596-19c8-49bd-8d4e-a8863b6ff9a0.pdf (accessed on 9 November 2020).

15. Gurevich, V. Protection of Substation Critical Equipment against Intentional Electromagnetic Threats; Wiley Blackwell: Hoboken, NJ, USA, 2017.

16. Foster, J.-S.; Gjelde, E.; Graham, W.-R.; Hermann, R.-J.; Kluepfel, H.-M.; Lawson, R.-L.; Soper, G.-K.; Wood, L.-L.; Woodard, J.-B. Report of the Commission to assess the Threat to the United States from Electromagnetic Pulse (emp) Attack: Critical National Infrastructures. 2008. Available online: http://www.empcommission.org/docs/A2473-EMP_Commission-7MB.pdf (accessed on 9 November 2020).

17. Hung, F.-S.; Hung, F.-Y.; Chiang, C.-M. Crystallization and annealing effects of sputtered tin alloy films on electromagnetic interference shielding. Appl. Surf. Sci. 2011, 257, 3733-3738. [CrossRef]

18. Guan, H.; Liu, S.; Duan, Y.; Cheng, J. Cement based electromagnetic shielding and absorbing building materials. Cem. Concr. Compos. 2006, 28, 468-474. [CrossRef]

19. Song, K.; Pan, F.S.; Chen, X.H.; Zhang, Z.H.; Tang, A.T.; She, J.; Yu, Z.W.; Pan, H.C.; Xu, X.Y. Effect of texture on the electromagnetic shielding property of magnesium alloy. Mater. Lett. 2015, 157, 73-76. [CrossRef]

20. Luo, Z.; Chen, X.-H.; Song, K.; Liu, C.-Q.; Dai, Y.; Zhao, D.; Pan, F.-S. Effect of Alloying Element on Electromagnetic Interference Shielding Effectiveness of Binary Magnesium Alloys. Acta Metall. Sin. (Engl. Lett.) 2019, 32, 817-824. [CrossRef]

21. Pandey, R.; Tekumalla, S.; Gupta, M. Enhanced (X-band) microwave shielding properties of pure magnesium by addition of diamagnetic titanium micro-particulates. J. Alloys Compd. 2019, 770, 473-482. [CrossRef]

22. Chen, X.-H.; Liu, L.-Z.; Liu, J.; Pan, F.-S. Enhanced electromagnetic interference shielding of Mg-Zn-Zr alloy by Ce addition. Acta Metall. Sin. (Engl. Lett.) 2015, 28, 492-498. [CrossRef]

23. Gupta, A.K.; Bafna, M.; Srivastava, S.; Khanna, R.K.; Vijay, Y.K. Study of electromagnetic shielding effectiveness of metal oxide polymer composite in their bulk and layered forms. Environ. Sci. Pollut. Res. 2020. [CrossRef] 
24. Yuan, S.M.; Ma, C.C.; Chuang, C.Y.; Yu, K.C.; Yen, W.S.; Yang, C.C.; Win, M.H. Effect of processing method on the shielding effectiveness of electromagnetic interference of MWCNT-PMMA. Compos. Sci. Technol. 2008, 68, 963-968. [CrossRef]

25. Panwar, V.; Kang, B.; Park, J.-O.; Park, S.; Mehra, R.-M. Study of dielectric properties of styrene-acrylonitrile graphite sheets composites in low and high frequency region. Eur. Polym. J. 2009, 45, 1777-1784. [CrossRef]

26. Kim, J.-T.; Park, C.-W.; Kim, B.-J. A study on synergetic EMI shielding behaviors of Ni-Co alloy-coated carbon fibers-reinforced composites. Synth. Met. 2017, 223, 212-217. [CrossRef]

27. Nasouri, K.; Shoushtari, A.-M. Designing, modeling and manufacturing of lightweight carbon nanotubes/polymer composite nanofibers for electromagnetic interference shielding application. Compos. Sci. Technol. 2017, 145, 46-54. [CrossRef]

28. Thomassin, J.-M.; Jérôme, C.; Pardoen, T.; Bailly, C.; Huynen, I.; Detrembleur, C. Polymer/carbon based composites as electromagnetic interference (EMI) shielding materials. Mater. Sci. Eng. R Rep. 2013, 74, 211-232. [CrossRef]

29. Varela-Rizo, H.; de Oca, G.-H.; Rodriguez-Pastor, I.; Monti, M.; Terenzi, A.; Martin-Gullon, I. Analysis of the electrical and rheological behavior of different processed CNF/PMMA nanocomposites. Compos. Sci. Technol. 2012, 72, 218-224. [CrossRef]

30. Al-Saleh, M.-H.; Gelves, G.-A.; Sundararaj, U. Copper nanowire/polystyrene nanocomposites: Lower percolation threshold and higher EMI shielding. Compos. Part A Appl. Sci. Manuf. 2011, 42, 92-97. [CrossRef]

31. Al-Saleh, M.-H.; Sundararaj, U. Electromagnetic interference shielding mechanisms of CNT/polymer composites. Carbon 2009, 47, 1738-1746. [CrossRef]

32. Wang, R.-X.; Tao, X.-M.; Wang, Y.; Wang, G.-F.; Shang, S.-M. Microstructures and electrical conductance of silver nanocrystalline thin films on flexible polymer substrates. Surf. Coat. Technol. 2010, 204, 1206-1210. [CrossRef]

33. Guo, R.-H.; Jiang, S.-Q.; Yuen, C.-W.-M.; Ng, M.-C.-F. Effect of copper content on the properties of Ni-Cu-P plated polyester fabric. J. Appl. Electrochem. 2009, 39, 907-912. [CrossRef]

34. Yip, J.; Jiang, S.; Wong, C. Characterization of metallic textiles deposited by magnetron sputtering and traditional metallic treatments. Surf. Coat. Technol. 2009, 204, 380-385. [CrossRef]

35. Wei, Q.; Xiao, X.; Hou, D.; Ye, H.; Huang, F. Characterization of nonwoven material functionalized by sputter coating of copper. Surf. Coat. Technol. 2008, 202, 2535-2539. [CrossRef]

36. Bula, K.; Koprowska, J.; Janukiewicz, J. Application of cathode sputtering for obtaining ultra-thin metallic coatings on textile products. FIBRES Text. In East. Eur. 2006, 14, 75-79.

37. Jiang, S.-Q.; Newton, E.; Yuen, C.-W.-M.; Kan, C.-W. Chemical silver plating on cotton and polyester fabrics and its application on fabric design. Text. Res. J. 2006, 76, 57-65. [CrossRef]

38. Yuen, C.-W.-M.; Jiang, S.-Q.; Kan, C.-W.; Tung, W.-S. Influence of surface treatment on the electroless nickel plating of textile fabric. Appl. Surf. Sci. 2007, 253, 5250-5257. [CrossRef]

39. Savage, H.-S.; McCormack, R.-G. Arc-Sprayed Coatings for Electromagnetic Pulse Protection: Assessment of Physical and Electrical Properties (No. CERL-TR-M-89/15); Construction Engineering Research Lab (Army): Champaign, IL, USA, 1989.

40. Choe, H.-B.; Lee, H.-S.; Shin, J.-H. Experimental study on the electrochemical anti-corrosion properties of steel structures applying the arc thermal metal spraying method. Materials 2014, 7, 7722-7736. [CrossRef] [PubMed]

41. Lee, H.-S.; Choe, H.-B.; Baek, I.-Y.; Singh, J.-K.; Ismail, M.-A. Study on the Shielding Effectiveness of an Arc Thermal Metal Spraying Method against an Electromagnetic Pulse. Materials 2017, 10, 1155. [CrossRef]

42. Lee, H.-S.; Park, J.-H.; Singh, J.-K.; Choi, H.-J.; Mandal, S.; Jang, J.-M.; Yang, H.-M. Electromagnetic Shielding Performance of Carbon Black Mixed Concrete with Zn-Al Metal Thermal Spray Coating. Materials 2020, 13, 895. [CrossRef] [PubMed]

43. Song, K.; Pan, F.; Chen, X.; Tang, A.; Pan, H.; Luo, S. Effect of Zn content on electromagnetic interference shielding effectiveness of Mg-Zn alloys. Mater. Res. Innov. 2014, 18, S4-193-S4-197. [CrossRef]

44. Song, M.-K.; Hong, S.-M.; Park, J.-M. Coatings material for shielding of electromagnetic wave. Polym. Sci. Technol. 2001, 12, 689-697.

45. Grimberg, R. Electromagnetic metamaterials. Mater. Sci. Eng. B 2013, 178, 1285-1295. [CrossRef] 
46. Zhao, Q.; Liu, Y.; Abel, E.-W. Effect of Cu content in electroless Ni-Cu-P-PTFE composite coatings on their anti-corrosion properties. Mater. Chem. Phys. 2004, 87, 332-335. [CrossRef]

47. Yao, W.-L.; Xiong, G.; Yang, Y.; Huang, H.-Q.; Zhou, Y.-F. Effect of silica fume and colloidal graphite additions on the EMI shielding effectiveness of nickel fiber cement based composites. Constr. Build. Mater. 2017, 150, 825-832. [CrossRef]

48. Jiang, S.-X.; Guo, R.-H. Electromagnetic shielding and corrosion resistance of electroless Ni-P/Cu-Ni multilayer plated polyester fabric. Surf. Coat. Technol. 2011, 205, 4274-4279. [CrossRef]

49. Lee, H.S.; Park, J.H.; Singh, J.K.; Ismail, M.A. Protection of reinforced concrete structures of waste water treatment reservoirs with stainless steel coating using arc thermal spraying technique in acidified water. Materials 2016, 9, 753. [CrossRef] [PubMed]

50. Lee, H.-S.; Singh, J.-K. Influence of calcium nitrate on morphology and corrosion characteristics of ammonium phosphate treated Aluminum coating deposited by arc thermal spraying process. Corros. Sci. 2019, 146, 254-268. [CrossRef]

51. Lee, H.-S.; Park, J.-H.; Singh, J.-K.; Ismail, M.-A. Deposition of coating to protect waste water reservoir in acidic solution by arc thermal spray process. Adv. Mater. Sci. Eng. 2018, 1-13. [CrossRef]

52. Lee, H.-S.; Kwon, S.-J.; Singh, J.-K.; Ismail, M.-A. Influence of Zn and Mg alloying on the corrosion resistance properties of $\mathrm{Al}$ coating applied by arc thermal spray process in simulated weather solution. Acta Metall. Sin. (Engl. Lett.) 2018, 31, 591-603. [CrossRef]

53. Park, J.-H.; Singh, J.-K.; Lee, H.-S. Ozone resistance, water permeability, and concrete adhesion of metallic films sprayed on a concrete structure for advanced water purification. Coatings 2017, 7, 41. [CrossRef]

54. Lee, H.-S.; Singh, J.-K.; Ismail, M.-A. An effective and novel pore sealing agent to enhance the corrosion resistance performance of Al coating in artificial ocean water. Sci. Rep. 2017, 7, 41935. [CrossRef]

55. Lee, H.-S.; Singh, J.-K.; Park, J.-H. Pore blocking characteristics of corrosion products formed on Aluminum coating produced by arc thermal metal spray process in $3.5 \mathrm{wt}$ \% $\mathrm{NaCl}$ solution. Constr. Build. Mater. 2016, 113, 905-916. [CrossRef]

56. Lee, H.-S.; Singh, J.-K.; Ismail, M.-A.; Bhattacharya, C. Corrosion resistance properties of Aluminum coating applied by arc thermal metal spray in SAE J2334 solution with exposure periods. Metals 2016, 6, 55. [CrossRef]

57. ASTM D4935, Standard Test Method for Measuring the Electromagnetic Shielding Effectiveness of Planar Materials; American Society of Testing Materials: West Conshohocken, PA, USA, 2018.

58. Munalli, D.; Dimitrakis, G.; Chronopoulos, D.; Greedy, S.; Long, A. Electromagnetic shielding effectiveness of carbon fibre reinforced Composites. Compos. Part B Eng. 2019, 173, 106906. [CrossRef]

59. Tailor, S.; Modi, A.; Modi, S.-C. Thermally Sprayed Thin Copper Coatings by W-HVOF. J. Therm. Spray Technol. 2019, 28, 273-282. [CrossRef]

60. Tailor, S.; Vashishtha, N.; Modi, A.; Modi, S.-C. An Investigation on Splat and Flattening Behavior of Thermally Sprayed Copper on A Rough Surface: A New Approach. J. Therm. Spray Eng. 2020, 2, $37-42$.

61. Lee, H.-S.; Singh, J.-K.; Ismail, M.-A.; Bhattacharya, C.; Seikh, A.-H.; Alharthi, N.; Hussain, R.-R. Corrosion mechanism and kinetics of Al-Zn coating deposited by arc thermal spraying process in saline solution at prolong exposure periods. Sci. Rep. 2019, 9, 1-17. [CrossRef] [PubMed]

62. Bonabi, S.-F.; Ashrafizadeh, F.; Sanati, A.; Nahvi, S.-M. Structure and Corrosion Behavior of Arc-Sprayed Zn-Al Coatings on Ductile Iron Substrate. J. Therm. Spray Technol. 2018, 27, 524-537. [CrossRef]

63. Jang, J.-M.; Lee, H.-S. A Study on the Electrical Conductivity and Electromagnetic Pulse Shielding Characteristics of Metal Sprayed Coating. In Proceedings of the Korean Institute of Building Construction Conference 2020; The Korean Institute of Building Construction: Seoul, Korea, 2020; pp. 8-9.

64. Lu, N.-N.; Wang, X.-J.; Meng, L.-L.; Ding, C.; Liu, W.-Q.; Shi, H.-L.; Hu, X.-S.; Wu, K. Electromagnetic interference shielding effectiveness of magnesium alloy-fly ash composites. J. Alloys Compd. 2015, 650, 871-877. [CrossRef]

65. Schulz, R.-B.; Plantz, V.-C.; Brush, D.-R. Shielding theory and practice. IEEE Trans. Electromagn. Compat. 1988, 30, 187-201. [CrossRef]

66. Liu, Z.; Bai, G.; Huang, Y.; Ma, Y.; Du, F.; Li, F.; Guo, T.; Chen, Y. Reflection and absorption contributions to the electromagnetic interference shielding of single-walled carbon nanotube/polyurethane composites. Carbon 2007, 45, 821-827. [CrossRef]

67. Saini, P.; Choudhary, V.; Singh, B.; Mathur, R.; Dhawan, S. Polyaniline-MWCNT nanocomposites for microwave absorption and EMI shielding. Mater. Chem. Phys. 2009, 113, 919-926. [CrossRef] 
68. Tai, M.-F.; Kok, S.-L.; Mukai, K. EMI Shielding Performance by Metal Plating on Mold Compound. In Proceedings of the 37th International Electronics Manufacturing Technology (IEMT) Conference, George Town, Malaysia, 22-26 September 2016; pp. 1-4.

69. Simon, R.-M. EMI Shielding through conductive plastics. Polym. Plast. Technol. Eng. 1981, 17, 1-10. [CrossRef]

70. Lu, G.; Li, X.; Jiang, H. Electrical and shielding properties of ABS resin filled with nickel-coated carbon fibers. Compos. Sci. Technol. 1996, 56, 193-200. [CrossRef]

71. Ninghi, Y.H.; Du, F.; Xiaolin, X.H.; Gao, H.; Ma, Y.; Li, F.; Chen, Y.; Eklind, P.C. Electromagnetic interference (EMI) shielding of single walled carbon nanotube epoxy composites. Nanotubes 2006, 6, 1141-1145.

Publisher's Note: MDPI stays neutral with regard to jurisdictional claims in published maps and institutional affiliations.

(C) 2020 by the authors. Licensee MDPI, Basel, Switzerland. This article is an open access article distributed under the terms and conditions of the Creative Commons Attribution (CC BY) license (http://creativecommons.org/licenses/by/4.0/). 